11. Мудрый, И. В. Влияние химического загрязнения санитарного врача РФ от 25 сентября 2007 г. N 74 почвы на здоровье населения/ И. В. Мудрый // Гигиена и санитария,2008. - № 4. - С. 32-37.

12. Мотузова Г.В., Безуглова О.С. Экологический мониторинг почв :учебник/Г.В. Мотузова, О.С. Безуглова. М.: Академический Проект; Гаудеамус, 2007. 237c.

13. Гарицкая М.Ю. Оценка экологического состояния территории, прилегающей к Сакмарской ТЭЦ / М. Ю. Гарицкая, О. Н. Нечитайло // Вестник Оренбургского государственного университета. - 2005. №9. - С. 125- 128.

14. Орлов Д.С. Химия почв / Д.С. Орлов, Л.К. Садовников, Н.И. Суханова. М.: Высш. шк., 2006. -558 c.

15. Валеева Т.Н. Этапы большого пути ОАО «Мелеузовские минеральные удобрения» / Т.Н. Валеева, Т.И. Севостьянова. - г. Уфа: ООО ИПК «Лаки», 2006.

16. Официальный сайт ОАО «Мелеузовские минеральные удобрения». - Режим доступа: www.oaommu.ru.

17. Постановление Главного государственного "О введении в действие новой редакции санитарноэпидемиологических правил и нормативов СанПиН 2.2.1/2.1.1.1200-03 “Санитарно-защитные зоны и санитарная классификация предприятий, сооружений и иных объектов": Зарегистрировано в Минюсте РФ 25 января 2008 г. - Система ГАРАНТ. - Режим доступа: http://base.garant.ru.

18. Хомяков, Д. М. Эколого-экономические вопросы производства и потребления минеральных удобрений в России / Д. М. Хомяков, Б. В. Левин // ЭКиП: Экология и промышленность России, 2005. - N 1. - С. 30-33.

19. Методические указания к лабораторным работам по дисциплине специализации "Химия окружающей среды”/Т. Ф. Тарасова, О. В. Малыхина, М. Ю. Гарицкая. - Оренбург : ОГУ, 2001. - 16 с.

20. Методика "Критерии оценки экологической обстановки территорий для выявления зон чрезвычайной экологической ситуации и зон экологического бедствия" (утв. Минприроды РФ 30.11.1992)// КонсультантПлюс: справочная правовая система 1992-2015. - Режим доступа: http://www.consultant.ru.

\title{
CHEMICAL CONTAMINATION OF SOILS TERRITORIES ADJACENT TO THE JSC «MELEUZ MINERAL FERTILIZERS»
}

\author{
C.A. Kosacheva, a student at the Department of Ecology and Environmental Sciences \\ Orenburg State University, Orenburg (Russia) \\ M.Y. Garitskaya, candidate of biological sciences, Associate Professor, Department of Ecology and \\ Environmental Sciences \\ Orenburg State University, Orenburg (Russia) \\ A.I. Baitelova, candidate of biological sciences, Associate Professor, Department of Ecology and \\ Environmental Sciences \\ Orenburg State University, Orenburg (Russia)
}

L. A. Pikus, a student at the Department of Ecology and Environmental Sciences

Orenburg State University, Orenburg (Russia)

\begin{abstract}
Environmental pollution by industrial enterprises, leading to its degradation and impairing the health of the population remains an urgent concern of environmental social and economic importance. At present, more and more land is subject to man-made factors that alter the chemical composition of the soil. All this is the result of agricultural use of various pesticides, fertilizers, plant growth stimulants. But beyond that, many an important role in soil pollution are industrial emissions.

This article examines the impact of the enterprise for the production of mineral fertilizers - JSC «Meleuz Minetal Fertilizers» - the quality of soil and environmental situation developing at a location nearby. On a functional purpose, this area is an area of growing crops. Not very safe is that this site is located within the boundaries of the sanitary protection zone. Monitoring of soil at an early stage allows you to track incipient changes in the environment. To assess the ecological status of the study area were determined indicator of chemical pollution of soils sampled at different distances from the plant, and the ranking according to the degree of ecological trouble. The results of the analysis showed that the highest concentrations of pollutants found in soil samples taken at the minimum distance from the plant. This confirms the impact on the territory of priority chemical plant emissions.

Ranking in terms of chemical contamination of soils indicates that the territory adjacent to the JSC «Meleuz Mineral Fertilizers»», at all distances studied, should be referred to an area with critical ecological situation.

Keywords: concentration; the rate of chemical contamination; concentration ratio; ranking; the study area; the environmental situation.

\section{УДК 574.2 \\ ПОЛУЧЕНИЕ ЭКОЛОГИЧЕСКИ БЕЗОПАСНОЙ ПРОДУКЦИИ КОНЕВОДСТВА НА ОСНОВЕ КОМПЛЕКСНОГО ИССЛЕДОВАНИЯ СОДЕРЖАНИЯ ТЯЖЕЛЫХ МЕТАЛЛОВ В ПОЧВЕННОМ ПОКРОВЕ БАШКОРТОСТАНА}

(C) 2015
\end{abstract}

А.Б. Латыпов, кандидат биологических наук, доцент кафедры технологического образования Бирский филиал Башкирского государственного университета, Бирск(Россия)

Р.Я. Сафиханов, кандидат биологических наук, доцент, заместитель директора по учебной работе;

Аннотащия. Исследования различных природно - сельскохозяйственных зон Республики Башкортостан на содержание тяжелых металлов (ТМ) в почвах и кормах позволили оценить их биоаккумуляцию, влияние на организм лошадей и выявление районов с приемлемыми условиями для содержания и получения экологически безопасной продукции коневодства.

Для этого предполагается интенсификация продуктивного коневодства - организация на всех конефермах республики производства конины и кумыса, нагула и откорма лошадей, расширение ассортимента продуктов из конины и широкое приобщение населения к конному спорту. Мясо конины ценится, прежде всего, за наличие в нем полноценных белков, витаминов группы В, особенно ниацина. Оно содержит большое количество железа и 
важные микроэлементы: кобальт, йод, медь. По большинству показателей конское мясо считается равноценным говядине, но по содержанию важных аминокислот и микроэлементов и, особенно липотропных веществ, конина имеет значительное преимущество.

В настоящее время остро стоит проблема оценки доступности веществ почвы для растений. Несмотря на длительность её изучения, она не только не потеряла своей актуальности с точки зрения полезного питания растений, но и расширила свои границы за счет вопросов о поступлении из почвы в растения вредных веществ, токсичных для растений, животных и человека.

Важнейшие микроэлементы (например, $\mathrm{Cu}$. Zn. Mn, Pb, Cd) могут, помимо участия в биохимических процессах (фотосинтез, образование органо-минеральных соединений, дыхание, транформация веществ и др.), выполнять роль загрязняющих почвенный покров веществ и токсикантов для растений, животных и человека в случае превышения ПДК, так как эти тяжелые металлы - активные загрязнители экосистемы (например Pb, Zn и Cd - I класс опасности, $\mathrm{Cu}$ - II класс опасности, $\mathrm{Mn}$ - III класс опасности).

Ключевые слова: коневодство; содержание тяжелых металлов в почве и кормах.

Программа развития коневодства в Республики Башкортостан предусматривает сохранение и и совершенствование генофонда башкирской, орловской и русской рысистых, русской тяжеловозной пород лошадей, разведение племенных лошадей чистокровной верховой породы на территории РБ, полное обеспечение потребности лошадьми сельскохозяйственных предприятий, доведение качества племенных и спортивных лошадей до мировых стандартов. В результате реализации Программы предполагается интенсификация продуктивного коневодства организация на всех конефермах производства конины и кумыса, нагула и откорма лошадей, расширение ассортимента продуктов из конины и широкое приобщение населения к конному спорту.

Оно ценится, прежде всего, за наличие в нем полноценных белков, витаминов группы В, особенно ниацина. Оно содержит большое количество железа и важные микроэлементы: кобальт, йод, медь. По большинству показателей конское мясо считается равноценным говядине, но по содержанию важных аминокислот и микроэлементов и, особенно липотропных веществ, конина имеет значительное преимущество. В частности незаменимая аминокислота гистидин в белках конины содержится в больших количествах $(6,0-9,7 \%)$ по сравнению с говядиной $(3,2-4,1 \%)$. Кроме того, в конском мясе содержится значительное количество витамина А (до 20 мг \% в жире), тиамина $(0,07 \%)$, рибофлавина $(0,1$ мг \%) и никотинамида $(4,2$ мг \%).

В мясе якутских, казахских и башкирских лошадей при среднем содержании жира от 16 до $23 \%$ калорийность колеблется от 2100 до 2700 ккал. Мясо тощих рабочих лошадей башкирской породы в среднем содержится белка $18,5 \%$, жира $-15,7 \%$, воды $-63,6 \%$, в мясе жеребят - 18,$3 ; 12,0 ; 68,6 \%$, соответственно. Диетические пищевые достоинства конины обусловлены во многом биологической ценностью содержащегося в ней жира: он лекгоплавок, благоприятно влияет на обмен веществ человека и препятствует развитию атеросклероза и других болезней. Жир у лошади откладывается, главным образом, на стенках брюшной области, около почек, сальника, брыжейники, особенно в области шеи. Жир молодых лошадей содержат больше незаменимых жирных кислот и обладают большей биологической ценностью, чем жиры полновозрастных лошадей. Температура плавления конского жира изменяется в интервале $27,6-28,30 \mathrm{C}$ в зависимости от возраста лошади. Содержание холестерина в конских жирах зависит от их анатомо-топографического расположения: в подкожном паховом жире $-31,9 \%$; в подкожном жире крестца - 25 мг \%; жировом гребне шеи - 10,4 мг \%; околопочечном - 18,7 мг \%; жир брюшной стенки - 22,9 мг \%; брыжеечном - 12,5 мг\%. В жирах других видов сельскохозяйственных животных содержание холестерина составляет: в бараньем -29 мг \%, в говяжьем - 75 мг \%, в свином - 74-126 мг \%. На биологическую ценность жиров большое влияние оказывает состав рационов при кормлении. В жире лошадей, находившихся на рационе, состоявшем из сена, силоса и различных концентратов, суммарное количество незаменимых жирных кислот составило $10,7 \%$, а получавших траву и овес $-17,7 \%$. Сопоставление жирнокислотного состава рационов (по линолевой и линоленовой кислотам) показало, что качественный состав незаменимых жирныъх кислот депонироавнных жиров находится в прямой зависимости от их содержания в рационе. Именно поэтому наибольшее их количество отмечено в жирах лошадей, получавших в рационе траву. Установлена более высокая биологическая ценность подкожных и экстраперитональных жиров по сравнению с внутренними. Однако внутренние жиры в своем составе содержат наибольшее количество витамина А. Особенно богаты витамином А жиры конской печени. В 1 кг печени башкирских лошадей после нагула содержится 88,4 ME витамина А, в жире брюшной стенки - 15,8 ME, околопочечном жире - 17,5 $\mathrm{ME}$, подкожном паховом - 10,8 ME. Для увеличения мясной продуктивности лошадей используют весенний и осенний нагулы. Во время весеннего нагула у молодняка происходит наращивание мускульной ткани, а в период осеннего - в основном, накопление жира.

Эффективное развитие коневодства требует комплексных исследований и рационального использования биологических ресурсов. Однако в связи с их недостаточной изученностью для развития коневодства и получения высококачественной экологически чистой продукции назрела необходимость исследования степени загрязнения компонентов природных сред и кормовых ресурсов в различных природно-сельскохозяйственных зонах территории Башкортостана для оценки биоаккумуляции и негативного влияния экотоксикантов на организм лошадей.

В настоящее время остро стоит проблема оценки доступности веществ почвы для растений и, несмотря на длительность её изучения, не только не потеряла своей актуальности с точки зрения полезного питания растений, но и расширила свои границы за счет вопросов о поступлении из почвы в растения вредных веществ, токсичных для растений, животных и человека.

Важнейшие микроэлементы (например, $\mathrm{Cu}$. Zn. $\mathrm{Mn}, \mathrm{Pb}, \mathrm{Cd})$ могут помимо участия в биохимических процессах (фотосинтез, образование органоминеральных соединений, дыхание, транформация веществ и др.) выполнять роль загрязняющих почвенный покров веществ и токсикантов для растений, животных и человека в случае превышения ПДК, так как эти тяжелые металлы - активные загрязнители экосистемы (например $\mathrm{Pb}, \mathrm{Zn}$ и $\mathrm{Cd}$ - I класс опасности, $\mathrm{Cu}$ - II класс опасности, Mn - III класс опасности).

Цель настоящего исследования - изучение состояния и качества биологических ресурсов - почвенных, кормовых, организма лошади в четырех природносельскохозяйственных зонах территории Республики Башкортостан: Северной лесостепной (Бирский район), Южной лесостепной (Уфимский, Кармаскалинский районы), Предуральской лесостепной (Туймазинский 
район) и Зауральской лесостепной (Хайбуллинский район) по тяжелым металлам (ТМ), оценка их биоаккумуляции, влияние на организм лошадей и выявление районов с приемлемыми условиями для получения экологически безопасной продукции коневодства.

К загрязняющим почву ТМ относятся металлы с плотностью более 8 тыс. кг/м3 (кроме благородных и редких): $\mathrm{Pb}, \mathrm{Cu}, \mathrm{Zn}, \mathrm{Ni}, \mathrm{Cd}, \mathrm{Hg}, \mathrm{Co}, \mathrm{Sb}, \mathrm{Sn}, \mathrm{Be} . \mathrm{B}$ прикладных работах к списку тяхелых металлов нередко добавляют также Pt, Ag, W, Fe, Mn. Почти все тяжелые металлы токсичны. Антропогенное рассеивание этой группы загрязнителей (в том числе и в виде солей) в биосфере приводит к отравлению или угрозе отравления живого. Анализ литературных данных о содержании ТМ в природных зонах Башкортостана свидетельствует, что наибольшее распространение получили высокотоксичные цинк, свинец, кадмий (I класс опасности), умеренноопасная медь (II класс опасности) и малоопасный марганец (III класс опасности) ГОСТ 17.4.1.02-83.

В работе исследованы и проанализированы содержание ТМ в пробах почв, кормов (сено луговое, солома пшеничная, зернофураж), применяемых для кормления лошадей в исследованных районах, крови и мышечной ткани (конина) на содержание меди, цинка, свинца, марганца и кадмия.

Основными источниками загрязнений тяжелыми металлами являются крупные индустриальные центры, предприятия теплоэнергетики, автотранспорт с непрерывным ростом своего парка, промышленные предприятия.

Поступление ТM в почву происходит с атмосферными осадками, металлосодержащими (цинк, медь, ртуть) пестицидами, удобрениями. Значительное количество ТМ содержат фосфорные удобрения, в двойном суперфосфате содержание цинка составляет 38 мг/кг, меди - 14 мг/кг, свинца - 39 мг/кг, кадмия - 3,7 мг/ кг, никеля - 29,1 мг/кг. Известь по содержанию свинца и никеля близка к суперфосфату. Основным поставщиком в почву цинка служит навоз (111 мг/т). Калийные и азотные удобрения характеризуются наименьшим содержанием TM ( $\mathrm{Zn}, \mathrm{Cu}, \mathrm{Pb}, \mathrm{Ni})$, однако для кадмия это не характерно, его содержание в фосфорном удобрении составляет 3,90 мг/кг, а в извести достигает 5,35 мг/кг. Поступая в почву, ТМ концентрируются в поверхностном слое (0-20 см), где присутствуют в форме обменных ионов, входят в состав гумусовых веществ, карбонатов, оксидов. Кларки и фоновое содержание валовых форм ТМ в почвах указаны в таблице 1 .

Таблииа 1

Кларки и фоновое содержание валовых форм ТМ 6 почвах ** ГОСТ 17.4.06-86

\begin{tabular}{|l|l|l|ll|l|l|}
\hline \multirow{2}{*}{$№$} & \multirow{2}{*}{1} & \multicolumn{5}{|l|}{ Содержание ТМ в почвах, мг/кг } \\
\cline { 2 - 8 } 1 & $\begin{array}{l}\text { Дерново-подзолистые песчаные и } \\
\text { супесчаные }\end{array}$ & $\begin{array}{l}\text { Cd } \\
28\end{array}$ & 0,05 & 6 & Pb & Hg \\
2 & $\begin{array}{l}\text { Дерново-подзолистые } \\
\text { суглинистые и глинистые }\end{array}$ & 45 & 0,12 & 15 & 15 & 0,05 \\
\hline 3 & Серые лесные & 60 & 0,20 & 16 & 18 & 0,15 \\
\hline 4 & Черноземы & 68 & 0,24 & 20 & 25 & 0,20 \\
\hline 5 & Каштановые & 54 & 0,16 & 16 & 20 & 0,15 \\
\hline 6 & Кларк по Виноградову & 50 & - & 10 & 20 & 0,01 \\
\hline
\end{tabular}

Способность почвы уменьшать подвижность ТМ и снижать их поступление в растения определяется содержанием гумуса и величиной рН. Высокогумусные и тяжелые по гранулометрическому составу почвы обеспечивают большую подвижность ТМ, чем малогумусные и легкие по механическому составу. Для определения степени загрязнения почв необходимо знание среднего фонового содержания валовых форм ТМ в различных типах почв.

Из представленных данных следует, что имеет место существование различия в содержании ТМ в почвах различных типов. Поэтому для оценки степени загрязнения исследуемых почв необходимо сочетать эту информацию с конкретными результатами аналитического контроля незагрязненных почв. Следует отметить, что токсичность ТМ при одинаковой их концентрации может быть различной в зависимости от гранулометрического состава почвы и содержания органического вещества. Мобильная форма ТM, присутствующих в почве, претерпевает различные превращения, взаимодействуя с гумусом почвы. Абсолютное содержание ТМ в гумусовых веществах техногенно загрязненной почвы уменьшается в следующем ряду: $\mathrm{Zn}>\mathrm{Cu}>\mathrm{Pb}>\mathrm{Cd}>\mathrm{Mn}$. Основными продуктами реакции ТМ с гумусовыми веществами являются гуматы и фульваты тяжелых металлов, а также комплексные и хелатные соединения. Более высокой комплексообразующей способностью обладают фульвокислоты по сравнению с гуминовыми кислотами. Стабильность комплексных соединений гумусовых веществ с ТМ уменьшается в ряду: $\mathrm{Pb}>\mathrm{Cu}>\mathrm{Ni}>\mathrm{Co}>\mathrm{Zn}>\mathrm{Cd}>\mathrm{Mn}$. На миграционную способность ТМ в почве большое влияние оказывают кислотно-щелочные условия. Известно, что группа ТМ $(\mathrm{Cd}, \mathrm{Pb}, \mathrm{Cu}, \mathrm{Ni})$ обладает повышенной подвижностью в кислой среде и становится инертной при переходе к щелочной. Токсическое действие ТМ двояко: прямое и косвенное. Прямое действие обусловлено блокировкой реакций с участием ферментов или коагуляцией белков. Блокировка фермента связана с замещением исходного металла фермента на присутствующие в клетке в избытке ионы TM ( $\mathrm{Cu}, \mathrm{Zn}, \mathrm{Pb}, \mathrm{Cd}, \mathrm{Mn})$, уменьшая или полностью прекращая каталитическое действие фермента. Прямое влияние высокой концентрации ионов ТМ может сопровождаться и косвенным воздействием - переводом питательных веществ в недоступное состояние и создание голодной среды. У ослабленных растений эффект прямого токсикоза значительно усиливается.

Одним из отрицательных эффектов ТМ является снижение энергии фотосинтеза. Так, в нормальных условиях в результате фотосинтеза выделяется около 12000 ккал. Под влиянием загрязнения количество выделяемой растениями энергии снижается в несколько раз, что приводит к уменьшению продуктивности агроэкосистем, ослаблению энергии прорастания семян. Последнее ведет к гибели семян, увеличению норм высева и т.д., то есть увеличивает стоимость производства.

Под влиянием ТМ (например, свинца):

$$
\text { нарушается репродуктивная функция }
$$
актиномицетов; снижается

микроорганизма;

- уменьшается биологическая активность почвы.

Изменяется структура микробного ценоза в сторону увеличения грибного населения, что увеличивает опасность микотоксинового загрязнения. Предельно допустимые количества ТМ в почве приведены в таблице 2 .

Таблица 2

Предельно допустимые количества ТМ в почве* *Цитата по Л.В. Мосиной, 20002.

\begin{tabular}{|c|c|c|}
\hline \multirow{2}{*}{$№$} & Элемент (ТМ) & ПДК, мг/кг \\
\hline 1 & Ртуть & 2,1 \\
\hline 2 & Свинец & Хон +20 \\
\hline 3 & Хром & 0,05 \\
\hline 4 & Марганец & 1500 \\
\hline 5 & Ванадий & 150 \\
\hline 6 & Марганец Ванадий & $1000+100$ \\
\hline
\end{tabular}

Следует отметить исключительную сложность нормирования веществ в почве в силу особенностей самой почвы и огромного разнообразия её разновидностей. Поэтому в настоящее время имеются нормативы лишь для небольшого числа элементов. При определении загрязнения почвы металлами, для которых отсутствует ПДК, проводится сравнение 
загрязнения с естественным фоновым уровнем.

Учитывая неодинаковый токсичный эффект в разных почвах, для оценки опасности введены ориентировочнодопустимые концентрации (ОДК) ТМ.

Загрязнение почв также характеризуется с помощью коэффициента аномальности, выражающего отношение содержания металла в верхнем слое загрязненной почвы к его фоновому содержанию в том же слое. Загрязненной почвой принято считать такую, в которой содержание ТМ превышает соответствующий фоновый показатель в 2 - 3 paза.

Результаты определения валового содержания ТМ в почвах различных природно-сельскохозяйственных зон РБ, полученные в данной работе, представлены в таблице 3. Из этих данных следует, что в исследованных пробах содержание ТМ близко к существующим фоновым значениям, превышение содержания марганца и кадмия наблюдалось в пробах почв, представляющих Зауральскую степную зону. Для образцов этой зоны также характерны довольно высокие значения отношения концентрации ТМ (Стм) к соответствующим значениям ПДК (СТм/ ПДК), возрастающие в ряду следующим образом: $\mathrm{Pb}: \mathrm{Cd}: \mathrm{Mn}: \mathrm{Cu}: \mathrm{Zn}:=0,47: 0,52:$ 0,63:0,80:0,88

Установлено достоверное отличие в содержании цинка $(\mathrm{td}=-2,03 ; \mathrm{P}<0,05)$ и кадмия $(\mathrm{td}=-3.09 ; \mathrm{P}<0,01)$ в образцах почв, представляющих Северную лесостепную и Зауральскую степную зоны

Таблица 3

Валовое содержание тяжельх металлов в почвах различных природно-сельскохозяйственных зон Башкортостана

\begin{tabular}{|c|c|c|c|c|c|c|}
\hline \multirow[b]{2}{*}{ № } & \multirow{2}{*}{$\begin{array}{l}\text { Природно- } \\
\text { сельскохоззйственная } \\
\text { Башкортостана (район РБ) }\end{array}$} & \multicolumn{5}{|c|}{ Концентрация ТМ в почвах, мг/kт } \\
\hline & & $\begin{array}{l}\text { Медь } \\
\mathrm{M} \pm \mathrm{m}\end{array}$ & $\begin{array}{l}\text { Цинк } \\
\mathrm{M} \pm \mathrm{m}\end{array}$ & $\begin{array}{l}\text { Марганец } \\
\mathrm{M} \pm \mathrm{m}\end{array}$ & $\begin{array}{l}\text { Свинец } \\
\mathrm{M} \pm \mathrm{m}\end{array}$ & $\begin{array}{l}\text { Кадмий } \\
\mathrm{M} \pm \mathrm{m}\end{array}$ \\
\hline 1 & $\begin{array}{l}\text { Северная лесостепная зона } \\
\text { - Бирский }\end{array}$ & $14,5 \pm 2,8$ & $23,5 \pm 4,7^{*}$ & $655 \pm 131$ & $13,3 \pm 2,7$ & $0,18 \pm 0,04 * *$ \\
\hline 2 & $\begin{array}{l}\text { Южная лесостепная зона } \\
\text { - Уфимский } \\
\text { - Кармаскалинский }\end{array}$ & $\begin{array}{l}19,7 \pm 3,9 \\
21,8 \pm 4,4\end{array}$ & $\begin{array}{l}34,4 \pm 6,8 \\
36,2 \pm 7,2\end{array}$ & $\begin{array}{l}765 \pm 153 \\
740 \pm 148\end{array}$ & $\begin{array}{l}16,2 \pm 3,2 \\
19,8 \pm 4,0\end{array}$ & $\begin{array}{l}0,38 \pm 0,07 \\
0,21 \pm 0,04\end{array}$ \\
\hline 3 & $\begin{array}{l}\text { Предуральская лесостепная } \\
\text { зона }\end{array}$ & & & & & \\
\hline 4 & $\begin{array}{l}\text { - Туймазинский } \\
\text { Зауральская степная зона } \\
\text { - Хайбуллинский }\end{array}$ & $14,2 \pm 2,7$ & $32,4 \pm 6,4$ & $790 \pm 158$ & $15,2 \pm 3,0$ & $0,34 \pm 0,06$ \\
\hline 5 & Фоновое содержание *** & $\begin{array}{l}24,0 \pm 4,6 \\
8-25\end{array}$ & $\begin{array}{l}44,0=9,0 \% \\
28-68\end{array}$ & $\begin{array}{l}940 \pm 190 \\
800-860\end{array}$ & $\begin{array}{l}15,5 \pm 3,0 \\
6-20\end{array}$ & $\begin{array}{l}0,52 \pm 0,10^{* *} \\
0,05-0,24\end{array}$ \\
\hline 6 & пдK & 30 & 50 & 1500 & 32 & 1,0 \\
\hline
\end{tabular}

$n=8 ; \quad * P_{-}<0.05, \quad * * P_{-}<0.01 ; \quad$ ***T.M. Мосина, 2000.

Тяжелые металлы, поступая в растения, неравномерно распределяются в их органах и тканях. Уровень накопления ТМ в репродуктивных органах растений значительно ниже, чем в вегетативных. Он определяется биологическими особенностями культуры, физиологической ролью элемента, его содержанием в почве и доступностью растениям. Познание неравномерности аккумуляции ТМ в кормах может в значительной степени ограничить их поступление в организм животных и человека, снизив тем самым их негативные последствия

Таким образом, как видно из проведенных исследований (табл. 3), содержание $\mathrm{Cu}, \mathrm{Zn}, \mathrm{Mn}$ и $\mathrm{Pb}$ в изучаемых районах находится ниже фоновых значений, однако по $\mathrm{Cd}$ Уфимский, Хайбуллинский и Туймазинский районы имеют превышение 1,5-2 раза над фоновым. Наиболее экологически безопасным районом по содержанию приоритетных ТМ в почвенном покрове является Бирский район республики Башкортостан.

Для кормов сельскохозяйственных животных установлены нормативы содержания ТМ, при этом значения ПДК для различных кормов (грубых и сочных, зернофуража) приняты одинаковыми.

Выполненные в данной работе исследования содержания ТМ в кормах различного вида (сено луговое, солома пшеничная, зернофураж), произведенных в различных зонах РБ, свидетельствуют об изменении показателей в широких пределах (таблица 4): от 2,6 до 11,5 109 мг/кг для меди; от 7,1 до 35,3 мг/кг для цинка; от 28,8 до 102,6 мг/кг для марганца; от 0,5 до 4,7 мг/кг для свинца; от 0,03 до 0,41 мг/кг для кадмия.

Таблииа 4

Концентрация тяжельх металлов в кормах, производимых в различных зонах Башкортостана

\begin{tabular}{|c|c|c|c|c|c|c|}
\hline \multirow[b]{2}{*}{ № } & \multirow{2}{*}{$\begin{array}{l}\text { Природно- сельскохозяйссвенная } \\
\text { зона Башкортостана (район РБ) }\end{array}$} & \multicolumn{5}{|c|}{ Концентрация ТМ в кормах, мг/кт } \\
\hline & & $\begin{array}{l}\text { Медь } \\
\mathrm{M} \pm \mathrm{m}\end{array}$ & \begin{tabular}{|l|} 
Цинк \\
$\mathrm{M} \pm \mathrm{m}$
\end{tabular} & \begin{tabular}{|l|} 
Марганец \\
$\mathrm{M} \pm \mathrm{m}$
\end{tabular} & $\begin{array}{l}\text { Свинец } \\
\mathrm{M} \pm \mathrm{m}\end{array}$ & $\begin{array}{l}\text { Кадмий } \\
\mathrm{M} \pm \mathrm{m}\end{array}$ \\
\hline 1 & $\begin{array}{l}\text { Северная лесостепная зона } \\
\text { - Бирский: } \\
\text { сено } \\
\text { солома } \\
\text { зернофураж }\end{array}$ & $\begin{array}{l}3,6 \pm 0,8 * \\
6,7 \pm 1,3 \\
4,2 \pm 0,8\end{array}$ & $\begin{array}{l}12,8 \pm 2,8 \\
10,1 \pm 2,4 \\
5,3 \pm 1,2\end{array}$ & $\begin{array}{l}62,3 \pm 12,1^{*} \\
47,7 \pm 8,5 \\
38,1 \pm 7,5\end{array}$ & $\begin{array}{l}2,0 \pm 0,4 \\
3,2 \pm 0,6 \\
0,5 \pm 0,1\end{array}$ & $\begin{array}{l}0,12 \pm 0,04^{*} \\
0,10 \pm 0,03 \\
0,03 \pm 0,01\end{array}$ \\
\hline 2 & $\begin{array}{l}\text { Южсная лесостепная зона } \\
\text { - Уфимский: } \\
\text { сено } \\
\text { солома } \\
\text { зернофураж } \\
\text { - Кармаскалинский: } \\
\text { сено } \\
\text { солома } \\
\text { зернофураж }\end{array}$ & $\begin{array}{l}3,3 \pm 0,7 * \\
4,2 \pm 0,8 \\
4,7 \pm 0,9 \\
\\
5,2 \pm 1,1 \\
6,8 \pm 1,3 \\
3,1 \pm 1,0\end{array}$ & $\begin{array}{l}14,1 \pm 3,0^{*} \\
11,4 \pm 2,3 \\
7,7 \pm 1,5 \\
\\
17,2 \pm 3,5^{*} \\
15,3 \pm 3,0 \\
7,1 \pm 1,5\end{array}$ & $\begin{array}{l}73,4 \pm 15,0^{*} \\
58,5 \pm 12,0 \\
46,8 \pm 10,0 \\
\\
68,2 \pm 14,0^{*} \\
61,4 \pm 12,3 \\
42,6 \pm 8,5\end{array}$ & $\begin{array}{l}3,5 \pm 0,7 \\
4,000,8 \\
0,6 \pm 0,1 \\
3,8 \pm 0,8 \\
4,7 \pm 1,0 \\
0,8 \pm 0,2\end{array}$ & $\begin{array}{l}0,33 \pm 0,10 \\
0,21 \pm 0,06 \\
0,07 \pm 0,02 \\
0,16 \pm 0,05 * \\
0,12 \pm 0,04 \\
0,04 \pm 0,01\end{array}$ \\
\hline 3 & $\begin{array}{l}\text { Предуральская лесостенная зона } \\
\text { - Туймазинский: } \\
\text { сено } \\
\text { солома } \\
\text { зернофураж }\end{array}$ & $\begin{array}{l}2,6 \pm 0,5^{*} \\
5,5 \pm 1,1 \\
3,3 \pm 0,7\end{array}$ & $\begin{array}{l}13,0 \pm 2,6 \\
10,1 \pm 2,0 \\
8,5 \pm 1,7\end{array}$ & $\begin{array}{l}56,3 \pm 11,3 * \\
46,2 \pm 9,2 \\
28,8 \pm 5,8\end{array}$ & $\begin{array}{l}2,1 \pm 0,4 \\
3,4 \pm 0,7 \\
0,7 \pm 0,2\end{array}$ & $\begin{array}{l}0,26 \pm 0,08 * \\
0,18 \pm 0,05 \\
0,06 \pm 0,02\end{array}$ \\
\hline 4 & $\begin{array}{l}\text { Зауральская степная зона } \\
\text { - Хайбуллинский. } \\
\text { сено } \\
\text { солома } \\
\text { зернофураж }\end{array}$ & $\begin{array}{l}3,8 \pm 0,8^{*} \\
11,5 \pm 2,3 \\
5,9 \pm 1,2\end{array}$ & $\begin{array}{l}19,1 \pm 4,0^{*} \\
35,3 \pm 7,0 \\
13,8 \pm 2,7\end{array}$ & $\begin{array}{l}81,5 \pm 16,2^{*} \\
102,6 \pm 20,5 \\
58,9 \pm 11,8\end{array}$ & $\begin{array}{l}2,6 \pm 0,5 \\
3,6 \pm 0,7 \\
0,6 \pm 0,1\end{array}$ & $\begin{array}{l}0,41 \pm 0,12 \\
0,30 \pm 0,10 \\
0,10 \pm 0,03\end{array}$ \\
\hline & $\Pi д K$ & 30,0 & 50,0 & - & 5,0 & 0,3 \\
\hline
\end{tabular}

$n=18 ; * P-<0.05$.

Из приведенных данных также следует, что максимальное содержание ТМ (меди, цинка, марганца и кадмия) характерно для кормов, произведенных в Зауральской степной зоне Республики Башкортостан (Хайбуллинский район). Наблюдается превышение концентрации кадмия над соответствующими значениями ПДК в грубых кормах Хайбуллинского района. Имеет место повышенное содержание свинца в кормах (сено, солома), производимых в Южной лесостепной зоне (Уфимский, Кармаскалинские районы).

В целом, наименьшей загрязненностью тяжелыми металлами характеризуются корма, произведенные в Северной лесостепной зоне (Бирский район).

Загрязнение кормов тяжелыми металлами способствует увеличению их поступления в организм лошадей. Результаты исследования концентраций ТМ в мышечной ткани лошадей различных зон территории Башкортостана, приведены в таблице 5. Из представленных данных следует, что наблюдается повышенное содержание ТМ в образцах Зауральской степной зоны. Полученные данные свидетельствуют о превышении нормативных значений концентрации свинца и кадмия в исследованных образцах, представляющих различные районы РБ.

Наибольшее содержание свинца характерно для образцов мяса лошадей, выращенных в Южной лесостепной зоне (Уфимский и Кармаскалинский районы), существенное превышение ПДК кадмия обнаружено в образцах мяса Уфимской и Хайбуллинской районов.

Таблииа 5

Содержание тяжелых металлов в мышечной ткани лошадей различных природно-сельскохозяйственных зон Башкортостана

\begin{tabular}{|c|c|c|c|c|c|c|}
\hline \multirow[b]{2}{*}{ № } & \multirow[b]{2}{*}{$\begin{array}{l}\text { Природно- сельскохозяйственная зона } \\
\text { Башкортостана (район РБ) }\end{array}$} & \multicolumn{5}{|c|}{ Концентрация ТМ в мышщах, мг/кт } \\
\hline & & $\begin{array}{l}\text { Медь } \\
\mathrm{M} \pm \mathrm{m}\end{array}$ & $\begin{array}{l}\text { Цинк } \\
\mathrm{M} \pm \mathrm{m}\end{array}$ & $\begin{array}{l}\text { Mapraнeц } \\
\mathrm{M} \pm \mathrm{m}\end{array}$ & \begin{tabular}{|l|} 
Свинец \\
$\mathrm{M} \pm \mathrm{m}$ \\
\end{tabular} & \begin{tabular}{|l} 
Кадмий \\
$\mathrm{M} \pm \mathrm{m}$
\end{tabular} \\
\hline 1 & $\begin{array}{l}\text { Северная лесостепная зона: } \\
\text { - Бирский (n=8) }\end{array}$ & $2,5 \pm 0,2^{*}$ & $17,4 \pm 2,3 * *$ & $1,3 \pm 0,1^{*}$ & $0,8 \pm 0,2^{*}$ & $0,08 \pm 0,01^{*}$ \\
\hline 2 & $\begin{array}{l}\text { Южная лесостепная зона: } \\
\text { - Уфимский (n=7) } \\
\text { - Кармаскалинский }(\mathrm{n}=8)\end{array}$ & $\begin{array}{l}2,0 \pm 0,1 \\
2,6 \pm 0,3\end{array}$ & $\begin{array}{l}20,5 \pm 2,6 \\
24,4 \pm 3,2\end{array}$ & $\begin{array}{l}1,6 \pm 0,3 \\
1,5 \pm 0,2\end{array}$ & $\begin{array}{l}1,2 \pm 0,3^{*} \\
1,4 \pm 0,4^{*}\end{array}$ & $\begin{array}{l}0,20 \pm 0,02^{* *} \\
0,10 \pm 0,02^{* *}\end{array}$ \\
\hline 3 & $\begin{array}{l}\text { Предуральская лесостепная зона: } \\
\text { - Туймазин ский }(\mathrm{n}=8)\end{array}$ & $1,8 \pm 0,1$ & $19,5 \pm 2,0$ & $1,2 \pm 0,1$ & $0,9 \pm 0,2^{*}$ & $0,16 \pm 0,03^{* *}$ \\
\hline 4 & $\begin{array}{l}\text { Зауральская степная зона: } \\
\text { - Хайбуллинский }(\mathrm{n}=7) \\
\end{array}$ & $3,6 \pm 0,4^{*}$ & $42,0 \pm 4,5 * *$ & $2,2 \pm 0,4^{*}$ & $1,0 \pm 0,3^{*}$ & $0,24 \pm 0,04^{* * *}$ \\
\hline 5 & пдк & 5,0 & 20 & $0,1-2,5$ & 0,5 & 0,05 \\
\hline
\end{tabular}

$* P_{-}<0.05 ; \quad * * P_{-}<0.001$.

Самарский научный вестник. 2015. № 2(11) 
Кровь в организме животного занимает особое место, осуществляя общую регуляцию жизненно - важных функций организма путем переноса питательных веществ. Она совместно с лимфой и тканевой жидкостью, окружая клетки, образует внутреннюю среду организма, постоянство состава которой крайне необходимо для нормальной жизнедеятельности всех органов и тканей. Сохраняя постоянство состава, кровь тем не менее является лабильной системой, быстро отражающей происходящие в организме изменения как в норме, так и в патологии. Наибольшее содержание эритроцитов $(8,8 \cdot 1012 / л)$ и более высокий уровень гемоглобина (146,5 г/л) в крови наблюдались в пробах, отобранных у животных, представляющих наименее загрязненную тяжелыми металлами Северную лесостепную зону (таблица 6). Повышенное содержание тяжелых металлов в организме лошадей Зауральской степной зоны вызывает снижение количества эритроцитов до 5,8・1012/л и понижение уровня гемоглобина до 116,0 г/л.

Таблица 6

Морфологический состав крови лошадей территории Башкортостана

\begin{tabular}{|c|c|c|c|c|}
\hline № & $\begin{array}{l}\text { Природно- сельскохозяйст венная } \\
\text { зона Башкортостана (район РБ) }\end{array}$ & $\begin{array}{l}\text { Показатели } \\
\text { зритроциты, } \\
\text { х1012/ת }\end{array}$ & $\begin{array}{l}\text { лейкоциты, } \\
\text { х10\%/л }\end{array}$ & $\begin{array}{l}\text { гемоглобин, } \\
\text { г/л }\end{array}$ \\
\hline 1 & $\begin{array}{l}\text { Северная лесостепная зона: } \\
\text { - Бирский }(\mathrm{n}=8)\end{array}$ & $8,8 \pm 1,2$ & $6,5 \pm 0,5$ & $146,5 \pm 8,3 *$ \\
\hline 2 & $\begin{array}{l}\text { Южная лесостепная зона: } \\
\text { - Уфимский (n=7) } \\
\text { - Кармаскалин ский (n=8) }\end{array}$ & $\begin{array}{l}6,5 \pm 0,8 \\
6,9 \pm 0,9\end{array}$ & $\begin{array}{l}5,6 \pm 0,6 \\
6,1 \pm 0,7\end{array}$ & $\begin{array}{l}128,4 \pm 6,8 \\
124,1 \pm 8,1\end{array}$ \\
\hline 3 & $\begin{array}{l}\text { Предуральская лесостепная зона: } \\
\text { - Туймазинский }(\mathrm{n}=8)\end{array}$ & $7,5 \pm 1,0$ & $6,6 \pm 0,8$ & $130,0 \pm 7,5$ \\
\hline 4 & $\begin{array}{l}\text { 3ауральская степная зона: } \\
\text { - Хайбуллин ский }(\mathrm{n}=7)\end{array}$ & $5,8 \pm 0,6$ & $8,2 \pm 1,0$ & $116,0 \pm 6,3$ \\
\hline 5 & $\begin{array}{l}\text { Среднее значение } \\
\text { нормативных показателей }\end{array}$ & $\frac{6-9}{7,5}$ & $\frac{7-12}{9,5}$ & $\frac{80-130}{105}$ \\
\hline
\end{tabular}

В результате проведенных исследований было установлено достоверное различие между средними значениями числа лейкоцитов в крови лошадей из Северной лесостепной и Зауральской степными зонами (td $=2,22 ; \mathrm{P}<0,05)$, представляющими территории с различной степенью негативного влияния тяжелых металлов. Значения данного показателя возрастают в интервале $(6,5-8,2) \cdot 109 / л$ и не выходят за пределы нормальных колебаний (7-12) •109/л.

Выводы

Проведено комплексное изучение степени загрязнения почвенного покрова и кормовых ресурсов основных природно-сельскохозяйственных зон Башкортостана тяжелыми металлами $(\mathrm{Cu}, \mathrm{Zn}, \mathrm{Mn}$, $\mathrm{Pb}, \mathrm{Cd})$ для оценки их биоаккумуляции, возможного негативного влияния на организм лошадей и выявления районов с приемлемыми условиями для получения экологически безопасной продукции коневодства.

Определено валовое содержание ТМ в почвах Северной, Южной лесостепной, Предуральской лесостепной и Зауральской степной зон. Установлено, что в исследованных образцах почв содержание ТМ близко к соответствующим фоновым значениям

Определена концентрация ТМ в мышечной ткани лошадей из различных зон Республики Башкортостан, показано повышенное их содержание в образцах, представляющих Зауральскую степную зону по сравнению с таковой для Северной лесостепной зоны:

В результате изучения морфологических и биохимических показателей крови лошадей обнаружено достоверное отличие концентрации эритроцитов $(\mathrm{td}=2,24 ; \mathrm{p}<0,05)$ и уровня гемоглобина $(\mathrm{td}=2,43 ; \mathrm{p}<0,05)$ у образцов, представляющих Северную лесостепную и Зауральскую степную зоны. Снижение количества эритроцитов (до 5,8・1012/л) и уровня гемоглобина (до 116,0 г/л) связано с повышенным содержанием тяжелыхметаллов в биопробах Зауральской степной зоны.

\section{СПИСОК ЛИТЕРАТУРЫ}

1. Авцын А.П. Микроэлементозы человека / А.П. Авцын, А.А. Жаворонков, М.А. Риш, Л.С. Строчкова. - М.: Медицина, 1991. - 496 с.

2. Ахатова И.А. Башкирская лошадь / И.А. Ахатова // Ватандаш. - 1999. - №2. - С. 42-49.

3. Ахатова И.А. К вопросу о селекции по качественному составу молока в коневодстве / И.А. Ахатова // Вестник сельскохозяйственной науки. 1994. - №2. - C. 45-47.

4. Ахатова И.А. Молочное коневодство РБ и конкурентоспособная целебная продукция / И.А. Ахатова // Экологическая экономика и устойчивое развитие: от глобальной модели к региональной практике: Материалы рос. науч.- практ. конф. - Уфа, 2002.- C. 38.

5. Ахатова И.А. Технологические требования к производству молока для детского и диетического питания / И.А. Ахатова, А.Г. Зорин // Аграрная наука производству: Сб. науч. тр. - Уфа, 2001. - С. 72.

6. Ахатова И.А. Технологические требования к производству кобыльего молока для детского и диетического питания / И.А. Ахатова, В.С. Мурсалимов, А.Г Зорин // Аграрная наука - производству: Сб. науч. тр. - Уфа, 2001. - С. 74.

7. Ахатова И.А. Основные принципы обеспечения экологической безопасности молочного сырья для детского и диетического питания в условиях РБ / И.А. Ахатова, А.Г. Зорин // На пути к новым технологиям: Тез. докл. регион. науч.-практ. конф. молодых ученых и специалистов. - Уфа: 2000. - С. 62- 64.

8. Ахатова И.А. Основные элементы технологии производства кобыльего молока в качестве сырья для детского и диетического питания в условиях Республики Башкортостан / И.А. Ахатова, А.Г. Зорин // Перспективы коневодства России в 21 веке: Тез. докл. науч.-практ. конф. и координационного совещания, посвященного 70-летию ВНИИКа. - Дивово: ВНИИК, 2000. - С. 19-22.

9. Бабенко Г.А. Микроэлементы в экспериментальной и клинической медицине / Г.А. Бабенко. - Киев, 1965. $-286 \mathrm{c}$.

10. Курамшина Н.Г. Комплексная система биологического мониторинга природных сред Башкотостана. Экологический мониторинг тяжелых металлов / Н.Г. Курамшина, Э.М. Курамшин, В.А. Вахитов // Сб. материалов Междунар. НТК, Магнитогорск, 1997. - С. 6.

11. Курамшина Н.Г. Степень загрязнения и экотоксичность поверхностных вод Республики Башкортостан и оценка влияния этого фактора на здоровье населения / Н.Г. Курамшина, Р.Ф. Халимов // Водохозяйственный комплекс Республики Башкортостан: экологические проблемы, состояние, перспективы: Сб. докл. Респ. науч.-практ. конф. - Уфа, 2005. - C. $100-105$.

12. Курамшина Н.Г. Экотоксикологическое изучение и рациональное использование биологических ресурсов Башкортостана / Курамшина Н.Г., А.Б. Латыпов, Э. М. Курамшин. // Проблемы региональной экологии. М.: 2005. - №3. - С. 18-21.

13. Курамшина Н.Г. Оценка экологического риска в западных районах РБ и разработка методов паллиативной защиты населения / Н.Г. Курамшина, 3.С. Терегулова, Э.М. Ахмадеева // Конференция по западу АН РБ, 1999. $-7 \mathrm{c}$.

14. Курамшина Н.Г. Интегральная экологическая оценка территории Башкортостана по биотестировнаию кормпродукции на инфузориях STYLONYCYIF MYTILUS / Н.Г. Курамшина, Э.М. Курамшин, А.Р. Хадыев // Сб. тр. I межд. конф. «Актуальные проблемы производства и переработки продуктов животноводства и птицеводства». - Уфа, 2000, C. $166-167$.

15. Курамшина Н.Г. Влияние антропогенного 
воздействия на трансформацию земель Уральского региона Башкортостана / Н.Г. Курамшина, Р.Ш. Кашапов, И.К. Хабиров, Р.Ф. Халимов // Сб. матов Межрегионального постоянно действующего научнотехнического семинара. - Пенза, 2001. - С. 56-58.

16. Курамшина Н.Г. Оценка опасности экотоксикологических факторов на репродуктивное здоровье в РБ / Н.Г. Курамшина, А.Д. Назыров, Э.М. Курамшин, И.М. Байкина, М.М. Садыков // Журнал «Экологические системы и приборы». - Москва, 2002. C. 30-33.

17. Курамшина Н.Г. Западный Башкортостан: «Экология и безопасность жизнедеятельности» Н.Г. Курамшина, Р.Ш. Кашапов, В.Ф. Коновалов, Л.Н. Мартыненкова, Л.М. Карамова // Монография. Уфа, 2003. - $136 \mathrm{c}$.

18. Курамшина Н.Г. Комплексный экологический мониторинг водных экосистем в условиях техногенеза / Н.Г. Курамшина// Сб. док-ов Республ. НПК «Водохозяйственный комплекс РБ: экол. пробл., состояние перспективы». - Уфа, 2005. - С. 61-68.

19. Курамшина Н.Г. Биоаккумуляция тяжелых металлов и влияние на морфологические и биотехнические показатели крови лошади в регионах Башкортостана / Н.Г. Курамшина, Р.Р. Мухаметшина // Материалы ВНПК г. Бирск 15-16 сентября 2005 г. «Современные тенденции в биологических науках XXI века». - С. 91-95.

20. Курамшина Н.Г. Биоиндикация поверхностных вод в условиях влияния г. Уфы / Н.Г. Курамшина, А.Д. Назыров, А.Х. Нафикова, Р.Р. Мухаметшина // Водохозяйственный комплекс Республики Башкортостан: экологические проблемы, состояние, перспективы: Сб. докл. Респ. науч.-практ. конф. - Уфа, 2005. - С. 79-88.

21. Латыпов, А.Б. Влияние на морфологические и биохимические показатели крови лошади биоаккумуляции тяжелых металлов в регионах Республики Башкортостан / А.Б. Латыпов, Н.Г. Курамшина // Биологические науки в XXI веке. Проблемы и тенденции развития / Сб. науч.труд. Междунар. НПК, Бирск:, 2005.- С.97-99. Скальный, А.А. Жаворонков и др. - М.: Изд-во КМК, 2000. - 540 с.

\section{PRODUCTION OF ENVIRONMENTALLY SAFE PRODUCTS OF HORSE BREEDING BASED ON A COMPREHENSIVE STUDY OF THE CONTENT OF HEAVY METALS IN THE SOIL COVER OF BASHKORTOSTAN \\ (C) 2015}

A.B. Latypov, candidate of biological sciences, assistant professor of technological education Bashkir State University, Birsk (Russia)

R.Y. Safihanov, candidate of biological sciences, Associate Professor, Deputy Director for Academic Affairs

Annotation. Study of different natural and agricultural areas of the Republic of Bashkortostan on the content of heavy metals (HMs) in soils and forages has bioaccumulation, assess their effects on the body of horses and the identification of areas with acceptable terms for environmentally safe products and horse breeding. To do this requires the intensification of productive breeding-organization at all konefermah of the production of horse meat and drink, foraging and feeding horses, expanding the range of products of horse meat and broader participation of equestrian sport. Horse meat is prized primarily for its high-grade protein, b vitamins, especially niacin. It contains a large amount of iron and important microelements of cobalt, iodine, copper. By most measures is equivalent to beef horsemeat, but on the content of essential amino acids and microelements, especially lipotropic substances, horse meat has a considerable advantage.

At present, the problem of assessing the availability of soil nutrients for plants, and in spite of the length of the study not only has not lost its relevance in terms of useful plants, but also expanded its borders through questions on the flow from soil into plants of harmful substances, toxic to plants, animals and humans. Essential trace elements (e.g., $\mathrm{Cu} \mathrm{Zn}$. Mn, $\mathrm{Pb}$, CD) are in addition to the biochemical processes (photosynthesis, formation of organic-mineral compounds, respiration, transformation of substances, etc.) perform the role of polluting the soil cover substances and toxicants for plants, animals and humans in case of exceeding of MPC, since these heavy metals-active contaminants ecosystems (such as $\mathrm{Pb}, \mathrm{Zn}$ and Cd-I CU-hazard class, hazard class, Mn (II)-(III) hazard class).

Keywords: Equine; contents of heavy metals in the soil and feed.

УДК 616-053.3

НЕКОТОРЫЕ АСПЕКТЫ ПАТОГЕНЕЗА ИШЕМИЧЕСКИ-ГИПОКСИЧЕСКИХ ПОРАЖЕНИЙ ЦЕНТРАЛЬНОЙ НЕРВНОЙ СИСТЕМЫ У НОВОРОЖДЕННЫХ

Л.В. Ледяйкина, доктор медицинских наук, доцент, доцент кафедры педиатрии Мордовский государственный университет им. Н.П.Огарева, Саранск (Россия)

Л.А. Балыкова, доктор медицинских наук, профессор, директор Медицинского института, заведующий кафедрой педиатрии

Мордовский государственный университет им. Н.П.Огарева, Саранск (Россия)

А.B. Герасименко, доктор медицинских наук, директор

Мордовский Республиканский клинический перинатальный центр, Саранск (Россия)

C.B. Гарина, кандидат медицинских наук, старший преподаватель кафедры педиатрии Мордовский государственный университет им. Н.П.Огарева, Саранск (Россия)

О.Н. Солдатова, кандидат медицинских наук, старший преподаватель кафедры педиатрии Мордовский государственный университет им. Н.П.Огарева, Саранск (Россия)

А.А. Толкунова, ординатор кафедры педиатрии

Мордовский государственный университет им. Н.П.Огарева, Саранск (Россия)

А.А. Страдина, врач-неонатолог

Мордовский Республиканский перинатальный центр, г. Саранск (Россия)

Аннотация. Проблема перинатальной заболеваемости в условиях недостаточно высокой рождаемости в России является на сегодняшний день одной из наиболее актуальных. Ведущими причинами перинатальной заболеваемости и смертности продолжают оставаться гипоксически-ишемические поражения головного мозга 